\title{
ANALYSING LARG SUPPLY CHAIN MANAGEMENT COMPETITIVE STRATEGIES IN IRANIAN CEMENT INDUSTRIES
}

\author{
Gholamreza Jamali, Elham Karimi Asl, \\ Sarfaraz Hashemkhani Zolfani, Jonas Šaparauskas
}

\section{Introduction}

Supply chain refers to the complex network of relationships that organizations maintain with trading partners in order to procure manufacture and deliver products to services (Maleki \& Cruz-Machado, 2013). From the supply chain as a network is expected to provide the right products and services on time with the required specifications at the right place to the customer.

In order to establish a strategic direction, planning for available and future opportunities requires a complete analysis of the whole chain. Today's dynamic and very variable, companies need to design and adopt their supply chain strategies that can assist them in improving their performance increased. Therefore, supply chain management (SCM) is considered a strategic factor for the better attainment of organizational goals such as enhanced competitiveness, improved customer service and increased profitability (Cabral et al., 2011b). Recently, the Lean, Agile, Resilient and Green (LARG) SCM paradigms had been adopted to improve the SC performance (Cabral et al., 2011b). In the other hand, in dynamic and changing markets, supply chain sustainability requires tools that can overcome environmental challenges and should be able to identify strengths, weaknesses, opportunities and threats in such competitive markets. The purpose of this article is to analyse LARG SCM competitive strategies in Iranian cement industries. These competitive strategies include Lean, Agile, Resilient, and Green (LARG) that could be implemented simultaneously.

\section{LARG SCM Strategies}

SCM is a value chain management from the supplier of a supplier to the customer of a customer of a company with the aim of attaining an overall value. Lean, Agile,
Resilient and Green are now at the forefront in management methods and SCM (EspadinhaCruz et al., 2011). The trade-offs between this managerial paradigms (LARG) are actual issues and may help supply chains to become more efficient, streamlined and sustainable. In a lean supply chain, profits maximize through cost reduction, while an agile supply chain maximizes profits through providing exactly what the customer requires (Carvalho et al., 2011). Lean focused on process improvements through the reduction or elimination of all "wastes" i.e., non-value adding operations, it embraces all the process through the product life cycle, starting with the product design to the product selling, from the customer order to the delivery. The agile supply chain paradigm intends to create the ability to quick respond and cost effectively to unpredictable changes in markets and increasing levels of environmental turbulence, both in terms of volume and variety. In the resilient supply chain may not be the lowest cost, but it is more capable of coping with the uncertain business environment. Also, environmental practices must be addressed to assure that the management system is sustainable (Carvalho et al., 2011).

Much has been written focusing on a single or integration a couple paradigms in SCM (Naylor et al., 1999; Christopher \& Rutherford, 2004; Kleindorfer \& Saad, 2005; Vonderembse et al., 2006; Kainuma \& Tawara, 2006; Rosič et al., 2009). However, it seems that integration of lean, agile, resilient, and green paradigms in a SCM may help supply chains to become more efficient, streamlined, and sustainable (Carvalho et al., 2011).

Organizations must implement a set of LARG practices that will have impact in the SC's competitiveness; the choice of which LARG practices are adequate is a complex problem to managers in the SC. It is important 


\begin{tabular}{|c|c|c|}
\hline LARG SCM Practices & Strategy & Reference \\
\hline Supplier relationships & Lean/Agile & $\begin{array}{c}\text { Anand \& Kodali, 2008; Gurumurthy \& } \\
\text { Kodal, 2009; Espadinha-Cruz et al., 2011; } \\
\text { Azevedo et al., } 2011\end{array}$ \\
\hline $\begin{array}{l}\text { Responsiveness improving speed to } \\
\text { change market needs }\end{array}$ & Agile & $\begin{array}{c}\text { Swafford et al., 2008; Carvalho et al., } \\
\text { 2011; Azevedo et al., } 2013\end{array}$ \\
\hline $\begin{array}{l}\text { Using total productive maintenance system } \\
\text { (TPM) }\end{array}$ & Lean & $\begin{array}{c}\text { Anand \& Kodal, 2008; Gurumurthy \& } \\
\text { Kodal, 2009; Modi \& Thakkar, 2014; } \\
\text { Bortolotti et al., } 2015\end{array}$ \\
\hline Processes standardization & Lean & $\begin{array}{l}\text { Anand \& Kodal, 2008; Gurumurthy \& } \\
\text { Kodal, 2009, Barac et al., } 2010\end{array}$ \\
\hline Energy consumption & Green & $\begin{array}{l}\text { Gonzalez et al., 2008; Holt \& Ghobadian, } \\
\text { 2009; Aksoy et al., } 2014 \text { Ahi et al., } 2016\end{array}$ \\
\hline Environmental waste & Green & $\begin{array}{l}\text { Paulraj, 2009; Carvalho \& Cruz-Machado, } \\
2011\end{array}$ \\
\hline $\begin{array}{l}\text { Filters and control for emission and } \\
\text { discharges }\end{array}$ & Green & Gonzalez et al., 2008; \\
\hline Suppliers' ISO14000 certification & Green & Holt \& Ghobadian, 2009; Hu \& Hsu, 2010 \\
\hline Supply chain risk management & Resilience & Carvalho et al., 2012; Wildgoose 2016; \\
\hline To use 3PL for transportations & Resilience & $\begin{array}{l}\text { Anand \& Kodali, 2008; Jayaram \& Tan, } \\
2010\end{array}$ \\
\hline New product development (NPD) & $\begin{array}{l}\text { Lean/Agile/ } \\
\text { Resilience }\end{array}$ & $\begin{array}{l}\text { Carvalho \& Cruz-Machado, 2011; Hasan } \\
\text { et al., } 2014\end{array}$ \\
\hline
\end{tabular}

Source: authors

to analyse how interoperable they are in order to guarantee successful deployment (Cabral et al., 2011a). Some of the most important studies related to the LARG SCM practices are summarized in Tab. 1.

In addition to the factors identified in the literature review, based on the 21 cement experts' opinions, 13 factors were scanned and selected using Delphi method (DM). Delphi is a decision making technique based on judgments of experts that concentrate on a special issue (Dalkey \& Helmer, 1963) for analysing, evaluating and finally forecasting the solution (Coates, 1974). It also called 'expert evaluation method' or 'expert grading method' and supposes that several experts are more unlikely to make a wrong decision rather than an expert over an issue (Hasson et al., 2000). It is also defined as "allowing a group of individuals, as a whole, to deal with a complex problem while avoiding their direct confrontation and retaining their interactions" (Linstone \& Turoff, 1975). DM applies procedure for developing a manageable strategy collecting scores for all factors in the strategy formulation so that the experts integrate their opinions, give feedback, and modify the score. This process is repeated until a satisfactory view is reached by each expert (Wang, 2011). Tab. 2. summarizes LARG requirements of SCM in Iranian cement industries derived from the Delphi method.

\section{Methodology}

\subsection{SWOT Analysis}

Identifying opportunities and threats, strengths and weaknesses (SWOT), organizations can 


\begin{tabular}{|c|c|}
\hline Tab. 2: & $\begin{array}{l}\text { LARG requirements of SCM in Iranian cement industries derived from Delphi } \\
\text { Method }\end{array}$ \\
\hline Row & LARG SCM Practices \\
\hline 1 & Operating profit and company's liquidity index \\
\hline 2 & Cement grinding capacity comparison with production capacity of clinker \\
\hline 3 & Suggestions system implementation \\
\hline 4 & Lack of technology, advanced and modern machinery \\
\hline 5 & Cement exports \\
\hline 6 & Increasing international cement price \\
\hline 7 & Investments in construction projects \\
\hline 8 & The effect of economic sanctions \\
\hline 9 & Government policy changes \\
\hline 10 & Number of competitors local in the cement industry \\
\hline 11 & Intensified competition in overseas markets \\
\hline 12 & Costs of fuel and transportation \\
\hline 13 & Orders size \\
\hline
\end{tabular}

develop strategies based on their strengths, weaknesses, gain maximum profit using opportunities and neutralize threats. Strengths and weaknesses are often internal to the organization, while opportunities and threats generally relate to external factors.

SWOT analysis is a powerful tool to aid decision-making and systematically analyzing the external and internal environment of an organization.

Generally, SWOT analysis works as a straightforward model that provides direction and serves as a basis for the development of marketing plans, accomplishing by assessing an organization's strengths (what an organization can do) and weaknesses (what an organization cannot do) in addition to opportunities (potential favorable conditions for an organization) and threats (potential unfavorable conditions for an organization) (Romero-Gutierrez et al., 2016).

Changes in weight of SWOT factors can cause changes in strategic priorities. It is important to use a method that measures the importance of each factor. This study offers a new method to prioritize the strategies including SO, ST, WO and WT using a decision making model (SWARA method). Generally, SWOT analysis does not provide complete measures and evaluations. However, it represents a basic reference for a valid strategy formulation. The main shortcoming of SWOT is that it provides only qualitative evaluations (Tavana et al., 2016). So, it seems we can overcome this problem through integrating SWOT analysis and SWARA technique.

\subsection{Step-Wise Weight Assessment Ratio Analysis (SWARA)}

One of the latest methods for evaluating criteria is SWARA which has been developing in different studies and applications since 2010 (Kersuliene et al., 2010). SWARA likes other MADM methods, is expert based and completely structured by experts' rules. Most other related MADM methods are based on pairwise comparisons like: AHP (Saaty, 1980), ANP (Saaty, 2001), FARE (Ginevicius, 2011) and BWM (Rezaei, 2015) but SWARA is completely different in this item.

SWARA method applied in different studies about decision making for expert and personnel selection (Kersuliene \& Turskis, 2011; Hashemkhani Zolfani \& Agha Banihashemi, 2014; Nabian, 2014); business issues (Hashemkhani Zolfani et al., 2013a); optimal alternative of mechanical longitudinal ventilation in tunnel pollutants (Hashemkhani Zolfani et al., 2013b); success factors of online games based on explorer (Hashemkhani Zolfani et al., 2013c); design of products 
(Hashemkhani Zolfani et al., 2013d Stanujkic et al., 2015; Karabašević et al., 2015); Building Structures Based on Local Climate (Hashemkhani Zolfani \& Zavadskas, 2013); machine tool selection (Aghdaie et al., 2013); prioritizing Sustainability Assessment Indicators of Energy System (Hashemkhani Zolfani \& Saparauskas, 2013); investment for high-tech industries (Hashemkhani Zolfani \& Bahrami, 2014); Evaluation of real-time intelligent sensors for structural health monitoring of bridges (Bitarafan et al., 2014); glasshouse locating (Haghnazar Kochaksaraei et al., 2015); Planning the priority of high tech industries (Ghorshi Nezhad et al., 2015); Technology Foresight about R\&D Projects Selection (Hashemkhani et al., 2015a); evaluation of strategies and scenarios (Hashemkhani Zolfani et al., 2015b; Hashemkhani Zolfani et al., 2016); Green supply chain management (Yazdani et al., 2016).

Mathematical part of SWARA is structured as the following: (Zavadskas et al., 2010; Yazdani et al., 2016).

Step 1 - Criteria ranked and sorted based on experts' attitudes.

Step 2 - From the second criterion, comparative importance of average value $S_{j}$ should be done as follows: the relative importance of criterion $j$ in relation to the previous $(j-1)$ criterion (Stanujkic et al., 2015).

Step 3 - Determine the coefficient $k_{j}$

$$
k_{j}=\left\{\begin{array}{cc}
1 & j=1 \\
s_{j}+1 & j>1
\end{array}\right.
$$

Step 4 - Determine the recalculated weight $q_{j}$

$$
q_{j}=\left\{\begin{array}{cc}
1 & j=1 \\
\frac{k_{j-1}}{k_{j}} & j>1
\end{array}\right.
$$

Step 5 - Final step in calculating criteria' weights

$$
w_{j}=\frac{q_{j}}{\sum_{k=1}^{n} q_{j}}
$$

where $w_{j}$ denotes the relative weight of criterion $j$.

\section{Results}

In this study, the following phases were used:

I) Designing external and internal factors matrix.
II) Analyzing SWOT matrix.

III) Positioning suitable strategy in the SPACE matrix.

IV) Designing Quantitative Strategic Planning Matrix (QSPM) and prioritization identified strategies.

\subsection{Designing External and Internal Factors Matrix}

The internal factors may be viewed as strengths or weaknesses depending upon their impact on the organization's objectives. What may represent strengths with respect to one objective may be weaknesses for another objective. A firm's strengths are its resources and capabilities that can be used as a basis for developing a competitive advantage. The absence of certain strengths may be viewed as a weakness. External environmental factors are normally outside our control, but can have a major impact on performance. It is important, therefore, that they are monitored and, where possible, forecast, and incorporated into strategic planning. As shown in Tab. 3., according to the internal factors (strengths and weaknesses) and external factors (opportunities and threats) weights for Iranian cement industries (derived from SWARA technique) and existing situation degree (based on experts opinion), existing situation weighted score for each factor have been calculated. So we can determine total weighted score for both internal and external factors.

\subsection{Analyzing SWOT Matrix}

One of the important purposes of SWOT analysis is to generate feasible alternative strategies. SWOT analysis shows the election possibility of four different strategies SO (Aggressive); WO (Conservative); WT (Defensive) and ST (Competitive) through a combination of internal factors and external factors matrix. However, in practice some of the strategies overlap with each other or simultaneously and harmoniously with each other and come into force. SWOT analysis for Iranian cement industries is shown in Tab. 4 according to the implementation of LARG SCM approach.

\subsection{Positioning Suitable Strategy in the SPACE Matrix}

Based on total scores of internal and external factors, we can evaluate Iranian cement 


\section{Ekonomika a management}

Tab. 3:

Analysis of internal and external factors in Iranian cement industries

\begin{tabular}{|c|c|c|c|}
\hline Strength & Weight & $\begin{array}{c}\text { Existing } \\
\text { Situation } \\
\text { Degree }\end{array}$ & $\begin{array}{c}\text { Existing } \\
\text { Situation } \\
\text { Weighted } \\
\text { Score }\end{array}$ \\
\hline Operating profit and company's liquidity index & 0.085 & 3 & 0.255 \\
\hline Filters and control for emission and discharges & 0.090 & 4 & 0.360 \\
\hline Using total productive maintenance system (TPM) & 0.070 & 4 & 0.281 \\
\hline responsiveness improving speed to change market needs & 0.090 & 3 & 0.269 \\
\hline Processes standardization & 0.092 & 4 & 0.366 \\
\hline $\begin{array}{l}\text { Cement grinding capacity comparison with production } \\
\text { capacity of clinker }\end{array}$ & 0.083 & 4 & 0.332 \\
\hline New product development & 0.085 & 3 & 0.256 \\
\hline Suggestions system implementation & 0.088 & 3 & 0.263 \\
\hline Total & 0.682 & & 2.382 \\
\hline \multicolumn{4}{|l|}{ Weakness } \\
\hline Energy consumption & 0.09 & 2 & 0.181 \\
\hline Environmental waste & 0.10 & 1 & 0.095 \\
\hline Costs of fuel and transportation & 0.04 & 1 & 0.042 \\
\hline Lack of technology, advanced and modern machinery & 0.09 & 2 & 0.179 \\
\hline Total & 0.318 & & 0.498 \\
\hline Total weighted score & 1 & & 2.880 \\
\hline \multicolumn{4}{|l|}{ Opportunity } \\
\hline Cement exports & 0.103 & 4 & 0.410 \\
\hline Increasing international cement price & 0.081 & 3 & 0.244 \\
\hline Investments in construction projects & 0.092 & 2 & 0.184 \\
\hline \multicolumn{4}{|l|}{ Supplier relationships } \\
\hline To use third-party logistics for transportations & 0.105 & 1 & 0.105 \\
\hline Suppliers' ISO14000 certification & 0.084 & 3 & 0.251 \\
\hline Total & 0.567 & & 1.603 \\
\hline \multicolumn{4}{|l|}{ Threat } \\
\hline The effect of economic sanctions & 0.049 & 1 & 0.049 \\
\hline Orders Size & 0.042 & 1 & 0.058 \\
\hline Supply chain risk management & 0.099 & 4 & 0.167 \\
\hline Government policy changes & 0.058 & 3 & 0.296 \\
\hline Number of competitors local in the cement industry & 0.093 & 2 & 0.186 \\
\hline Intensified competition in overseas markets & 0.093 & 2 & 0.187 \\
\hline Total & 0.433 & & 0.942 \\
\hline Total weighted score & 1 & & 2.545 \\
\hline
\end{tabular}




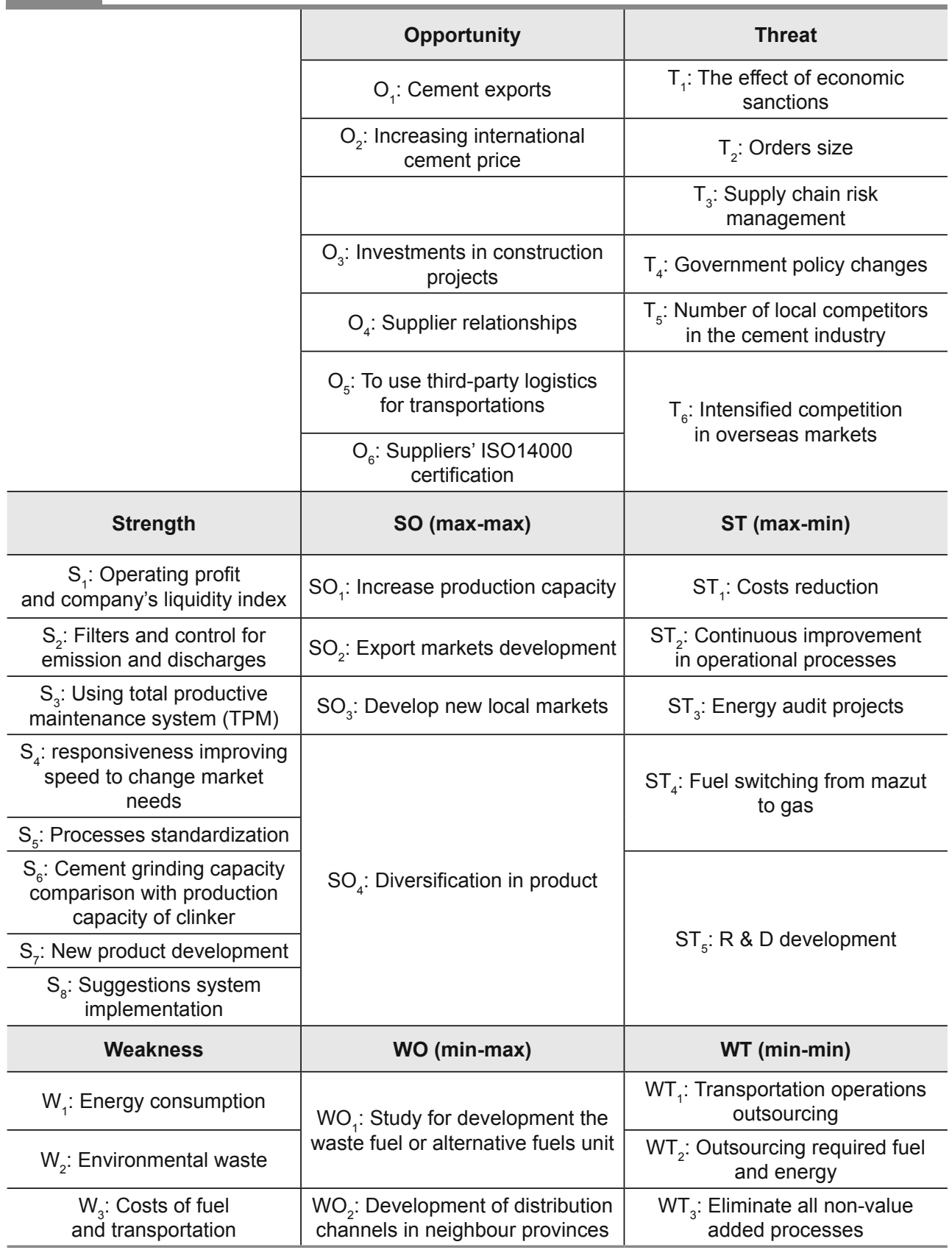




\begin{tabular}{c|c|c} 
Weakness & WO (min-max) & WT (min-min) \\
\hline \multirow{3}{*}{$\begin{array}{c}\mathrm{W}_{4}: \text { Lack of technology, } \\
\text { advanced and modern } \\
\text { machinery }\end{array}$} & $\begin{array}{c}\mathrm{WO}_{3} \text { : Customer orientation } \\
\text { and customer relationship } \\
\text { management (CRM) }\end{array}$ & $\begin{array}{c}\mathrm{WT}_{4}: \text { Reviews and improve } \\
\text { organizational structures and } \\
\text { operational processes }\end{array}$ \\
\cline { 2 - 3 } & & $\begin{array}{c}\mathrm{WT}_{5}: \text { Improve cement industry } \\
\text { holding activities according to the } \\
\text { international standards in order } \\
\text { to expand market share }\end{array}$ \\
\cline { 3 - 3 } & $\begin{array}{c}\mathrm{WT}_{6}: \text { Outsourcing non-major } \\
\text { activities using strategic alliances }\end{array}$ \\
\hline
\end{tabular}

industries strategy position. So we use the Strategic Position and Action Evaluation Matrix (SPACE MATRIX) to select an appropriate strategy. In the SPACE matrix we assessed Iranian cement industries across four dimensions include: Industry Attractiveness (IA), Environmental Stability (ES), Competitive Advantage (CA) and Financial Strength (FS). The SPACE diagram showed favourable positions in all four dimensions. Based on the results (derived from Tab. 3), scores of the internal factors evaluation (IFE) and external factors evaluation (EFE) was 2.88 and 2.55 respectively. That means Iranian cement industries can pursue an aggressive strategy as it leverages its strengths into the opportunities.
In the other word Strengths-opportunities (SO) strategies are based on using a firm's internal strengths to take advantage of external opportunities and threats. Fig. 2 shows the appropriate strategy position for the Iranian cement industries.

\subsection{Designing QSPM Matrix and Prioritization Identified Strategies}

The next stage in the strategy-formulation framework for the Iranian cement industries involves the Quantitative Strategic Planning Matrix. To objectively evaluate feasible alternative strategies identified in SWOT analysis, the QSPM uses input information derived from former stage. In the first step,

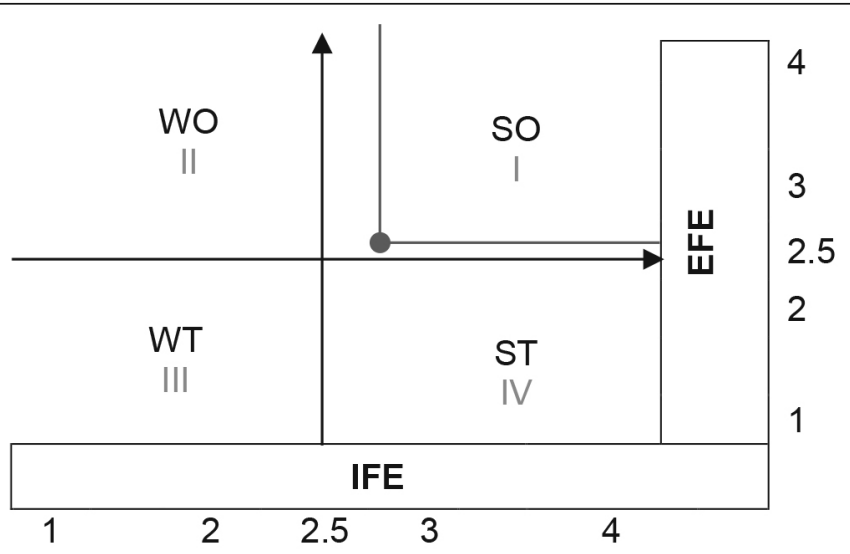


weights assigned to each external and internal factor. Total attractiveness scores are defined as the sum of the attractiveness scores in a given column of the QSPM and are calculated in the second step of the QSPM as shown in
Tab. 5 a positive feature of QSPM is that sets of strategies can be examined sequentially or simultaneously. Finally, as it seen in Tab. 6, based on the Total Attractiveness Score (TAS), each strategy could be prioritized.

\section{Tab. 5: Quantitative Strategic Planning Matrix (QSPM) - Part I}

\begin{tabular}{|c|c|c|c|c|c|c|c|c|c|}
\hline \multirow[t]{2}{*}{ Strength } & \multirow[t]{2}{*}{ Weight } & \multicolumn{2}{|c|}{$\begin{array}{c}\text { Strategy } \\
\mathrm{SO}_{1}\end{array}$} & \multicolumn{2}{|c|}{$\begin{array}{c}\text { Strategy } \\
\mathrm{SO}_{2}\end{array}$} & \multicolumn{2}{|c|}{$\begin{array}{c}\text { Strategy } \\
\mathrm{SO}_{3}\end{array}$} & \multicolumn{2}{|c|}{$\begin{array}{c}\text { Strategy } \\
\mathrm{SO}_{4}\end{array}$} \\
\hline & & AS & TAS & AS & TAS & AS & TAS & AS & TAS \\
\hline $\begin{array}{l}\mathrm{S}_{1} \text { : Operating profit and company's } \\
\text { liquidity index }\end{array}$ & 0.085 & 4 & 0.340 & 4 & 0.340 & 4 & 0.340 & 4 & 0.340 \\
\hline $\begin{array}{l}\mathrm{S}_{2}: \text { Filters and control for emission } \\
\text { and discharges }\end{array}$ & 0.090 & 4 & 0.360 & 4 & 0.360 & 4 & 0.360 & 4 & 0.360 \\
\hline $\begin{array}{l}\mathrm{S}_{3}: \text { Using total productive } \\
\text { maintenance system (TPM) }\end{array}$ & 0.070 & 4 & 0.280 & 4 & 0.280 & 4 & 0.280 & 4 & 0.280 \\
\hline $\begin{array}{l}\mathrm{S}_{4} \text { : responsiveness improving } \\
\text { speed to change market needs }\end{array}$ & 0.090 & 4 & 0.360 & 4 & 0.360 & 4 & 0.36 & 4 & 0.360 \\
\hline $\mathrm{S}_{5}:$ Processes standardization & 0.092 & 4 & 0.368 & 4 & 0.368 & 4 & 0.368 & 4 & 0.368 \\
\hline $\begin{array}{l}\mathrm{S}_{6}: \text { Cement grinding capacity } \\
\text { comparison with production } \\
\text { capacity of clinker }\end{array}$ & 0.083 & 4 & 0.332 & 3 & 0.249 & 3 & 0.249 & 3 & 0.249 \\
\hline $\mathrm{S}_{7}:$ New product development & 0.085 & 4 & 0.340 & 4 & 0.340 & 4 & 0.340 & 4 & 0.340 \\
\hline $\begin{array}{l}\text { S: Suggestions system } \\
\text { implementation }\end{array}$ & 0.088 & 2 & 0.176 & 2 & 0.176 & 2 & 0.176 & 2 & 0.176 \\
\hline Weakness & & AS & TAS & AS & TAS & AS & TAS & AS & TAS \\
\hline $\mathrm{W}_{1}$ : Energy consumption & 0.091 & 4 & 0.364 & 4 & 0.364 & 4 & 0.364 & 3 & 0.273 \\
\hline $\mathrm{W}_{2}$ : Environmental waste & 0.095 & 2 & 0.190 & 2 & 0.190 & 2 & 0.190 & 2 & 0.190 \\
\hline $\mathrm{W}_{3}:$ Costs of fuel and transportation & 0.042 & 3 & 0.126 & 4 & 0.168 & 4 & 0.168 & 2 & 0.084 \\
\hline $\begin{array}{l}\text { W: Lack of technology, advanced } \\
\text { and modern machinery }\end{array}$ & 0.090 & 4 & 0.360 & 4 & 0.360 & 4 & 0.360 & 4 & 0.360 \\
\hline Total scores of internal factors & 1 & & 3.595 & & 3.555 & & 3.555 & & 3.380 \\
\hline Opportunity & & AS & TAS & AS & TAS & AS & TAS & AS & TAS \\
\hline $\mathrm{O}_{1}$ : Cement exports & 0.103 & 4 & 0.412 & 4 & 0.412 & 4 & 0.412 & 3 & 0.309 \\
\hline $\begin{array}{l}\mathrm{O}_{2}: \text { Increasing international cement } \\
\text { price }\end{array}$ & 0.081 & 4 & 0.324 & 4 & 0.324 & 4 & 0.324 & 4 & 0.324 \\
\hline $\begin{array}{l}\mathrm{O}_{3}: \text { Investments in construction } \\
\text { projects }\end{array}$ & 0.092 & 4 & 0.368 & 1 & 0.092 & 4 & 0.368 & 2 & 0.184 \\
\hline $\mathrm{O}_{4}$ : Supplier relationships & 0.102 & 3 & 0.306 & 3 & 0.306 & 3 & 0.306 & 1 & 0.102 \\
\hline $\begin{array}{l}\mathrm{O}_{5}: \text { To use third-party logistics for } \\
\text { transportations }\end{array}$ & 0.105 & 3 & 0.315 & 4 & 0.420 & 4 & 0.420 & 1 & 0.105 \\
\hline $\begin{array}{l}\mathrm{O}_{6}: \text { Suppliers' ISO14000 } \\
\text { certification }\end{array}$ & 0.084 & 3 & 0.252 & 4 & 0.336 & 4 & 0.336 & 2 & 0.168 \\
\hline
\end{tabular}


Tab. 5: Quantitative Strategic Planning Matrix (QSPM) - Part II

\begin{tabular}{|c|c|c|c|c|c|c|c|c|c|}
\hline \multirow[t]{2}{*}{ Threat } & \multirow[t]{2}{*}{ Weight } & \multicolumn{2}{|c|}{$\begin{array}{l}\text { Strategy } \\
\text { SO }_{1}\end{array}$} & \multicolumn{2}{|c|}{$\begin{array}{c}\text { Strategy } \\
\mathrm{SO}_{2}\end{array}$} & \multicolumn{2}{|c|}{$\begin{array}{c}\text { Strategy } \\
\mathrm{SO}_{3}\end{array}$} & \multicolumn{2}{|c|}{$\begin{array}{c}\text { Strategy } \\
\mathrm{SO}_{4}\end{array}$} \\
\hline & & AS & TAS & AS & TAS & AS & TAS & AS & TAS \\
\hline $\begin{array}{l}\mathrm{T}_{1}: \text { The effect of economic } \\
\text { sanctions }\end{array}$ & 0.049 & 4 & 0.196 & 4 & 0.196 & 4 & 0.196 & 4 & 0.196 \\
\hline $\mathrm{T}_{2}:$ Orders size & 0.042 & 4 & 0.168 & 4 & 0.168 & 4 & 0.168 & 3 & 0.126 \\
\hline $\mathrm{T}_{3}$ : Supply chain risk management & 0.099 & 4 & 0.396 & 4 & 0.396 & 4 & 0.396 & 4 & 0.396 \\
\hline $\mathrm{T}_{4}:$ Government policy changes & 0.058 & 3 & 0.174 & 4 & 0.232 & 3 & 0.174 & 2 & 0.116 \\
\hline $\begin{array}{l}T_{5}: \text { Number of local competitors in } \\
\text { the cement industry }\end{array}$ & 0.093 & 4 & 0.372 & 2 & 0.186 & 4 & 0.372 & 3 & 0.279 \\
\hline $\begin{array}{l}\mathrm{T}_{6} \text { : Intensified competition in } \\
\text { overseas markets }\end{array}$ & 0.093 & 4 & 0.372 & 4 & 0.372 & 3 & 0.279 & 2 & 0.186 \\
\hline Total score of external factors & 1 & & 3.655 & & 3.440 & & 3.751 & & 2.491 \\
\hline Total scores of strategies & & & 7.251 & & 6.995 & & 7.306 & & 5.871 \\
\hline
\end{tabular}

Source: authors

\section{Tab. 6: Strategies priority}

\begin{tabular}{l|c|c}
\multicolumn{1}{c|}{$\begin{array}{c}\text { Strategic choice } \\
\text { with QSPM method }\end{array}$} & $\begin{array}{c}\text { Total score of the attractiveness } \\
\text { of each strategy }\end{array}$ & $\begin{array}{c}\text { Priority } \\
\text { of each strategy }\end{array}$ \\
\hline $\mathrm{SO}_{1}$ : Increase production capacity & 7.251 & 2 \\
\hline $\mathrm{SO}_{2}:$ Export markets development & 6.995 & 3 \\
\hline $\mathrm{SO}_{3}$ : Develop new local markets & 7.306 & 1 \\
\hline $\mathrm{SO}_{4}$ : Diversification in product & 5.871 & 4 \\
\hline
\end{tabular}

Source: authors

\section{Conclusions and Recommendations}

Internal and external environments of the organization are both important factors in determining strategies. Changes in each environment will cause changes in demands for products and services and also affect the supply chain. The internal environment includes weaknesses and strengths and the external environment includes opportunities and threats for the organization which can affect the organization's road map.

This study proposes a strategic analysis for LARG SCM competitive strategies in Iranian cement industries. We used the SPACE matrix to check if which strategy is appropriate. The results showed that the proper strategy was the aggressive strategy. In the SPACE matrix we assessed Iranian cement industries across four dimensions include: industry attractiveness, environmental stability, competitive advantage and financial strength. The SPACE diagram showed that Iranian cement industries can pursue an aggressive strategy as it has a strong competitive position in the market with rapid growth. The two big concerns in this competitive position are: 1) Avoid complacency - it seems that business is too easy but threats may come from new markets or as technology makes different sectors converge and 2) Avoid running foul of anticompetition policies. A business that is too strong may be able to attract the attention of regulators and especially if it uses predatory pricing aimed at driving competitors out of business.

Based on the SPACE analysis we recommend that Iranian cement industries in this position take the following actions: 
1. To use the internal strengths to develop market strategy. This can include product development, integration with other companies, and acquisition of competitors.

2. Iranian cement industries have a competitive advantage and can protect it, a key factor is the possible of new competitors' entry into the industry, it may be considered new acquisitions, increasing market share and focusing on competitive products.

3. Invest in innovation to sustain and develop the competitive advantage which exists.

4. Monitor any moves made by competitors to develop alternative competitive advantages. Create the opportunities to reach a diversified value proposition so that attractive to segments of the market.

5. To innovate new products and reduce prices to levels that competitors find difficult to match.

\section{References}

Aghdaie, M. H, Hashemkhani Zolfani., S., \& Zavadskas, E. K. (2013). Decision making in machine tool selection: an integrated approach with SWARA and COPRAS-G methods. Inzinerine Ekonomika - Engineering Economics, 24(1), 5-17. doi:10.5755/j01. ee.241.2822.

Ahi, P., Searcy, C., \& Jaber, M. Y. (2016). Energy-related performance measures employed in sustainable supply chains: A bibliometric analysis. Sustainable Production and Consumption, 7, 1-15. doi:10.1016/j. spc.2016.02.001.

Aksoy, A., Küçükoğlu, İ., Ene, S., \& Öztürk, N. (2014). Integrated emission and fuel consumption calculation model for green supply chain management. Procedia - Social and Behavioral Sciences, 109, 1106-1109. doi:10.1016/j.sbspro.2013.12.595.

Alimardani, M., Hashemkhani Zolfani, S., Aghdai, M. H., \& Tamosaitien, J. (2013). A Novel Hybrid SWARA and VIKOR Methodology for Supplier Selection in an Agile Environment. Technological and Economic Development of Economy, 19(3), 533-548. doi:10.3846/202949 13.2013.814606.

Anand, G., \& Kodali, R. (2008). A conceptual framework for lean supply chain and its implementation. International Journal of Value Chain Management, 2(3), 313-357. doi:10.1504/IJVCM.2008.019517.
Azevedo, S. G., Carvalho, H., \& CruzMachado, V. (2011). A proposal of LARG supply chain management practices and a performance measurement system. International Journal of e-Education, e-Business, e-Management and e-Learning, 1(1), 7-14.

Azevedo, S. G., Govindan, K., Carvalho, H., \& Cruz-Machado, V. (2013). Ecosilient Index to assess the greenness and resilience of the upstream automotive supply chain. Journal of Cleaner Production, 56, 131-146. doi:10.1016/j.jclepro.2012.04.011.

Barac, N., Milovanovic, G., \& Andjelkovic, A. (2010). Lean production and six sigma quality in lean supply chain management. Economics and Organization, 7(3), 319-334.

Bitarafan, M., Hashemkhani Zolfani, S., Lale Arefi, S., Zavadskas, E. K., \& Mahmoudzadeh, A. (2014). Evaluation of real-time intelligent sensors for structural health monitoring of bridges based on SWARA-WASPAS: a case in Iran. Baltic Journal of Road and Bridge Engineering, 9(4), 333-340.

Bortolotti, T., Boscari, S., \& Danese, P. (2015). Successful lean implementation: Organizational culture and soft lean practices. International Journal of Production Economics, 160, 182-201. doi:10.1016/j.jpe.2014.10.013.

Cabral, I., Espadinha-Cruz, P., Puga-Leal, R., Grilo, O., \& Cruz-Machado, V. (2011a). Decision making models for interoperable lean, agile, resilient and green supply chains. Proceedings of the International Symposium on the Analytic Hierarchy Process (pp. 1-6).

Cabral, I., Grilo, A. P., Leal, R., \& CruzMachado, V. (2011b). Modelling Lean, Agile, Resilient, and Green Supply Chain Management. In Information Technology Interfaces (ITI), Proceedings of the ITI 2011, 33rd International Conference on Information Technology Interfaces (pp. 365-369). IEEE.

Carvalho, H., \& Cruz-Machado, V. (2011). Integrating Lean, Agile, Resilience and Green Paradigms in Supply Chain Management (LARG_SCM). Faculdade de Ciencias e Tecnologia da Universidad Nova de Lisboa (pp. 27-48). INTECH Open Access Publisher.

Carvalho, H., Azevedo, S. G., \& Cruz-Machado, V. (2012). Agile and resilient approaches to supply chain management: influence on performance and competitiveness. Logistics Research, 4(1-2), 49-62. doi:10.1007/s12159-012-0064-2.

Carvalho, H., Duarte S., \& Cruz-Machado, V. (2011). Lean, agile, resilient and green: 
divergences and synergies. International Journal of Lean Six Sigma, 2(2), 151-179. doi:10.1108/20401461111135037.

Christopher, M., \& Rutherford, C. (2004). Creating supply chain resilience through agile Six Sigma. Critical Eye, June-August, 24-28.

Coates, J. F. (1974). Some methods and techniques for comprehensive impact assessment. Technological Forecasting and Social Change, 6, 341-357. doi:10.1016/0040-1625(74)90035-3.

Dalkey, N., \& Helmer, O. (1963). An experimental application of the Delphi method to the use of experts. Management Science, 9(3), 458-467. doi:10.1287/mnsc.9.3.458.

Espadinha-Cruz, P., Grilo, A., Puga-Leal, R., \& Cruz-Machado, V. (2011). A model for evaluating Lean, Agile, Resilient and Green practices interoperability in supply chains. In Industrial Engineering and Engineering Management (IEEM), 2011 IEEE International Conference on Industrial Engineering and Engineering Management (pp. 1209-1213). doi:10.1109/IEEM.2011.6118107.

Ghorshi Nezhad, M. R., Hashemkhani Zolfani, S., Moztarzadeh, F., Zavadskas, E. K., \& Bahrami, M. (2015). Planning the priority of high tech industries based on SWARA-WASPAS methodology: The case of the nanotechnology industry in Iran. Economic ResearchEkonomska Istraživanja, 28(1), 1111-1137. doi:10.1080/1331677X.2015.1102404.

Ginevicius, R. (2011). A new determining method for the criteria weights in multi-criteria evaluation. International Journal of Information Technology \& Decision Making, 10(6), 1067-1095. doi:10.1142/S0219622011004713.

Gonzalez, P., Sarkis, J., \& Adenso-Diaz, B. (2008). Environmental management system certification and its influence on corporate practices: Evidence from the automotive industry. International Journal of Operations \& Production Management, 28(11), 1021-1041. doi:10.1108/01443570810910179.

Gurumurthy, A., \& Kodali, R. (2009). Application of benchmarking for assessing the lean manufacturing implementation. Benchmarking: An International Journal, 16(2), 274-308. doi:10.1108/14635770910948268.

Haghnazar Kouchaksaraei, R., Hashemkhani Zolfani, S., \& Golabchi, M. (2015). Glasshouse locating based on SWARACOPRAS approach. International Journal of Strategic Property Management, 19(2), 111-122. doi:10.3846/1648715X.2015.1004565.
Hasan, S. M., Gao, J., Wasif, M., \& Iqbal, S. A. (2014). An integrated decision making framework for automotive product development with the supply chain. Procedia CIRP, 25, 8-10. doi:10.1016/j.procir.2014.10.004.

Hashemkhani Zolfani, S., \& Bahrami, M. (2014). Investment prioritizing in high tech industries based on SWARA-COPRAS approach. Technological and Economic Development of Economy, 20(3), 534-553. doi:10.3846/20294913.2014.881435.

Hashemkhani Zolfani, S., \& Saparauskas, J. (2013). New Application of SWARA Method in Prioritizing Sustainability Assessment Indicators of Energy System. Inzinerine Ekonomika - Engineering Economics, 24(5), 408-414. doi:10.5755/j01.ee.24.5.4526.

Hashemkhani Zolfani, S., \& Seyed Agha Banihashemi, S. (2014). Personnel selection based on a novel model of game theory and MCDM Approaches. 8th International Scientific Conference "Business and Management 2014", 15-16 May 2014. Vilnius, Lithuania (pp. 191-198). doi:10.3846/bm.2014.024.

Hashemkhani Zolfani, S., \& Zavadskas, E., K. (2013). Sustainable Development of Rural Areas' Building Structures Based on Local Climate. Procedia Engineering, 57, 1295-1301. doi:10.1016/j.proeng.2013.04.163.

Hashemkhani Zolfani, S., Aghdaie, M. H., Derakhti, A., \& Zavadskas, E., K. (2013a). Decision making on business issues with foresight perspective; an application of new hybrid MCDM model in shopping mall locating. Expert Systems with Applications, 40(17), 71117121. doi:10.1016/j.eswa.2013.06.040.

Hashemkhani Zolfani, S., Esfahani, M. H., Bitarafan, M., Zavadskas, E. K., \& Arefi, S. L. (2013b). Developing a new hybrid MCDM method forselection of the optimalalternative of mechanical longitudinal ventilation of tunnel pollutants during automobile accidents. Transport, 28(1), 89-96. doi:10.3846/16484142.2013.782567.

Hashemkhani Zolfani, S., Farrokhzad, M., \& Turskis, Z. (2013c). Investigating on successful factors of online games based on explorer. E\&M Ekonomie a Management, 16(2), 161-169.

Hashemkhani Zolfani, S., Zavadskas E. K., \& Turskis, Z. (2013d). Design of product is with both international and local perspectives based on YIN-YANG balance theory and SWARA method. Economic Research - Ekonomska Istraživanja, 26(2), 153-166. doi:10.1080/1331 677X.2013.11517613. 
Hashemkhani Zolfani, S., Salimi, J., Maknoon, R., \& Kildiene, S. (2015a). Technology Foresight about R\&D Projects Selection: application of SWARA method at the policy making level. Inzinerine Ekonomika - Engineering Economics, 26(5), 571-580. doi:10.5755/j01.ee.26.5.9571.

Hashemkhani Zolfani, S., Maknoon, R., \& Zavadskas, E. K. (2015b). Multiple nash equilibriums and evaluation of strategies, New application of MCDM methods. Journal of Business Economics and Management, 16(2), 290-306. doi:10.3846/16111699.2014.967715.

Hashemkhani Zolfani, S., Maknoon, R., \& Zavadskas, E. K. (2016). Multiple Attribute Decision Making (MADM) based Scenarios. International Journal of Strategic Property Management, 20(1), 101-111. doi:10.3846/164 8715X.2015.1132487.

Hasson, F., Keeney, S., \& McKenna, H. (2000). Research guidelines for the Delphisurvey technique. Journal of Advanced Nursing, 32(4), 1008-1015. doi:10.1046/j.1365-2648.2000.t011-01567.

Holt, D., \& Ghobadian, A. (2009). An empirical study of green supply chain management practices amongst UK manufacturers. Journal of Manufacturing Technology Management, 20(7), 933-956. doi:10.1108/17410380910984212.

Hu, A. H., \& Hsu, C. W. (2010). Critical factors for implementing green supply chain management practice: an empirical study of electrical and electronics industries in Taiwan. Management Research Review, 33(6), 586-608. doi:10.1108/01409171011050208.

Jayaram, J., \& Tan, K. C. (2010). Supply chain integration with third-party logistics providers. International Journal of Production Economics, 125(2), 262-271. doi:10.1016/j. ijpe.2010.02.014.

Kainuma, Y., \& Tawara, N. (2006). A multiple attribute utility theory approach to lean and green supply chain management. International Journal of Production Economics, 101, 99-108. doi:10.1016/j.ijpe.2005.05.010.

Karabašević, D., Stanujkić, D., \& Urošević, S. (2015). The MCDM Model for Personnel Selection Based on SWARA and ARAS Methods. Management, 77, 43-52. doi:10.7595/ management.fon.2015.0029.

Kersuliene, V., \& Turskis, Z. (2011). Integrated fuzzy multiple criteria decision making model for architect selection.
Technological and Economic Development of Economy, 17(4), 645-666. doi:10.3846/202949 13.2011.635718.

Kersuliene, V., Zavadskas, E. K., \& Turskis, Z. (2010). Selection of rational dispute resolution method by applying new step-wise weight assessment ratio analysis (SWARA). Journal of Business Economics and Management, 11(2), 243-258. doi:10.3846/jbem.2010.12.

Kleindorfer, P. R., \& Saad, G. H. (2005). Managing disruption risks in supply chains. Production and Operations Management, 14(1), 53-68. doi:10.1111/j.1937-5956.2005. tb00009.

Linstone, H. A., \& Turoff, M. (Eds.). (1975). The Delphi method: Techniques and applications (29). Reading, MA: AddisonWesley.

Maleki M., \& Cruz-Machado, V. (2013). Generic Integration of Lean, Agile, Resilient, and Green Practices in Automotive Supply Chain. Review of International Comparative Management, 14(2), 237-248.

Modi, D. B., \& Thakkar, H. (2014). Lean thinking: Reduction of waste, lead time, cost through lean manufacturing tools and technique. International Journal of Emerging Technology and Advanced Engineering, 3(4), 339-344.

Nabian, A. (2014). Resenting new MCDM framework based on SWARA-VIKOR in personnel selection, applied mathematics in Engineering. Management and Technology, 2(1), 28-36.

Naylor, J. B., Naim, M. M., \& Berry, D. (1999). Leagility: integrating the lean and agile manufacturing paradigms in the total supply chain. International Journal of Production Economics, 62(1-2), 107-118. doi:10.1016/ S0925-5273(98)00223-0.

Paulraj, A. (2009). Environmental motivations: a classification scheme and its impact on environmental strategies and practices. Business Strategy and the Environment, 18(7), 453-468. doi:10.1002/bse.612.

Power, D. (2005). Supply chain management integration and implementation: a literature review. Supply Chain Management: An International Journal, 10(4), 252-263. doi:10.1108/13598540510612721.

Rezaei, J. (2015). Best-worst multi-criteria decision-making method. Omega, 53, 49-57. doi:10.1016/j.omega.2014.11.009. 
Romero-Gutierrez, M., Jimenez-Liso, M. R., \& Martinez-Chico, M. (2016). SWOT analysis to evaluate the programme of a joint online/onsite master's degree in environmental education through the students' perceptions. Evaluation and Program Planning, 54, 41-49. doi:10.1016/j.evalprogplan.2015.10.001.

Rosič, H., Bauer, G., \& Jammernegg, W. (2009). A framework for economic and environmental sustainability and resilience of supply chains. In G. Reiner (Ed.), Rapid Modelling for Increasing Competitiveness. New York, NY: Springer (pp. 91-104). doi:10.1007/978-1-84882-748-6_8.

Saaty, T. L. (1980). The Analytic Hierarchy Process: Planning, Priority Setting, Resources Allocation. London: McGraw-Hill.

Saaty, T. L. (2001). Decision making with dependence and feedback: the analytic network process. Pittsburgh, PA: RWS Publications.

Stanujkic, D., Karabasevic, D., \& Zavadskas, E. K. (2015). A framework for the Selection of a packaging design based on the SWARA method. Inzinerine Ekonomika-Engineering Economics, 26(2), 181-187. doi:10.5755/j01. ee.26.2.8820.

Swafford, P. M., Ghosh, S., \& Murthy, N. (2008). Achieving supply chain agility through IT integration and flexibility. International Journal of Production Economics, 116(2), 288297. doi:10.1016/j.ijpe.2008.09.002.

Tavana, M., Zareinejad, M., Di Caprio, D., \& Kaviani, M. A. (2016). An integrated intuitionistic fuzzy AHP and SWOT method for outsourcing reverse logistics. Applied Soft Computing, 40, 544-557. doi:10.1016/j.asoc.2015.12.005.

Vonderembse, M. A., Uppal, M., Huang, S. H., \& Dismukes, J. P. (2006). Designing supply chains: towards theory development. International Journal of Production Economics, 100, 223-238. doi:10.1016/j.ijpe.2004.11.014.

Wang, G. Y. (2011). Civil Engineering's Comprehensive Evaluation Technology and Application. Beijing: China Water Conservancy and Electricity Press.
Wildgoose, N. (2016). Supply Chain Risk Management. A Common Framework for the Entire Organization, 75-87.

Yazdani, M., Hashemkhani Zolfani, S., \& Zavadskas, E. K. (2016). New integration of MCDM methods and QFD in the selection of green suppliers. Journal of Business Economics and Management, 17(6), 1097-1113. doi:10.38 46/16111699.2016.1165282.

Zavadskas, E. K., Turskis, Z., Ustinovichius, L., \& Shevchenko, G. (2010). Attributes Weights Determining Peculiarities in Multiple Attribute Decision Making Methods. Inzinerine Ekonomika-Engineering Economics, 21(1), 32-43.

Assist. Prof. Gholamreza Jamali, Ph.D. Persian Gulf University Department of Industrial Management gjamali@pgu.ac.ir

MSc. Elham Karimi AsI Persian Gulf University Department of Industrial Management Elh.karimiası@gmail.com

PhD candidate Sarfaraz Hashemkhani Zolfani Amirkabir University of Technology Department of Management, Science and Technology Technology Foresight Group and

Kerman University of Medical Sciences Health Services Management Research Center Institute for Futures Studies in Health sa.hashemkhani@gmail.com

Assoc. Prof. Jonas Šaparauskas, Ph. D. Vilnius Gediminas Technical University Faculty of Civil Engineering jonas.saparauskas@vgtu.It 


\section{Abstract}

\section{ANALYSING LARG SUPPLY CHAIN MANAGEMENT COMPETITIVE STRATEGIES IN IRANIAN CEMENT INDUSTRIES}

\section{Gholamreza Jamali, Elham Karimi AsI, Sarfaraz Hashemkhani Zolfani, Jonas Šaparauskas}

In the contemporary highly competitive international business environment companies have to exercise great care in devising entry strategies for foreign markets. Therefore, supply chain management (SCM) is considered a strategic factor for the better attainment of organizational goals such as enhanced competitiveness, improved customer service and increased profitability. Because the, Supply chain management as a vital challenge to the Cement industry and developing infrastructure as a whole has been posed by scholars. This article analyses Lean, Agile, Resilient, and Green (LARG) supply chain management competitive strategies in Iranian cement industries. The lean, agile, resilient and green SCM paradigms had been adopted to improve the SC performance. We used Step-wise Weight Assessment Ratio Analysis (SWARA) technique to weighting strengths, weaknesses, opportunities and threats (SWOT) based on LARG supply chain management practices for 11 Iranian cement companies. Then the Strategic Position and Action Evaluation (SPACE) matrix used to check if which strategy is appropriate. In the SPACE matrix we assessed Iranian cement industries across four dimensions include: Industry Attractiveness (IA), Environmental Stability (ES), Competitive Advantage (CA) and Financial Strength (FS). The results showed that Iranian cement industries can follow an aggressive strategy as it leverages its strengths into the opportunities. Iranian cement industries are also blessed because it has a good competitive advantage in an industry which is considered to be attractive. Among the strategic choices, develop new local markets strategy has the first priority, followed by the; Increase production capacity, Export markets development, Diversification in product with QSPM method. Finally, some actions recommended for Iranian cement industries in such a strong position.

Key Words: LARG SCM, SWARA, SWOT Analysis.

JEL Classification: L1.

DOI: 10.15240/tul/001/2017-3-005 